\title{
Influence of low oxygen and high carbon dioxide on shredded Galega kale quality for development of modified atmosphere packages
}

\author{
Susana C. Fonseca ${ }^{a}$, Fernanda A.R. Oliveira ${ }^{\mathrm{b}, *}$, Jeffrey K. Brecht ${ }^{\mathrm{c}}$, Khe V. Chau ${ }^{\mathrm{d}}$ \\ ${ }^{a}$ Escola Superior de Biotecnologia, Universidade Católica Portuguesa, Rua Dr. António Bernardino de Almeida, 4200-072 Porto, Portugal \\ ${ }^{\mathrm{b}}$ Department of Process Engineering, University College Cork, Cork, Ireland \\ ${ }^{\mathrm{c}}$ Horticultural Sciences Department, University of Florida, 1217 Fifield Hall, Gainesville, FL 32611-0690, USA \\ d Agricultural and Biological Engineering Department, University of Florida, 37 Frazier Rogers Hall, Gainesville, FL 32611-0570, USA
}

Keywords: Quality; Shelf life; Respiration rate; Sensory attributes; Colour; Chlorophyll; Ascorbic acid; Fresh-cut

\begin{abstract}
Respiration rate, sensory attributes, colour alterations, and water, chlorophyll and ascorbic acid contents were monitored during storage of shredded Galega kale (Brassica oleracea var. acephala DC.) at $20^{\circ} \mathrm{C}$ to define an adequate range of $\mathrm{O}_{2}$ and $\mathrm{CO}_{2}$ partial pressures for product preservation. Different low $\mathrm{O}_{2}$ and high $\mathrm{CO}_{2}$ atmospheres were tested. First, tolerance to low $\mathrm{O}_{2}$ partial pressures $\left(1,2,3\right.$ or $21 \mathrm{kPa} \mathrm{O}_{2}$ with balance $\left.\mathrm{N}_{2}\right)$ was tested. Quality retention was improved as $\mathrm{O}_{2}$ partial pressure was reduced and there was no induction of anaerobic respiration. Then, tolerance to high $\mathrm{CO}_{2}$ partial pressures $(0,10,15 \mathrm{or} 20 \mathrm{kPa}$ $\mathrm{CO}_{2}$ plus $21 \mathrm{kPa} \mathrm{O}$ and balance $\mathrm{N}_{2}$ ) was tested. The high $\mathrm{CO}_{2}$ partial pressures extended the shelf life of the shredded kale and no symptoms of $\mathrm{CO}_{2}$ injury were detected. Finally, combinations of low $\mathrm{O}_{2}$ and high $\mathrm{CO}_{2}\left(1\right.$ or $2 \mathrm{kPa} \mathrm{O}_{2}$ plus 15 or $20 \mathrm{kPa}$ $\mathrm{CO}_{2}$, with balance $\mathrm{N}_{2}$, and an air control) were analysed. No differences were observed among the different gas combinations. An atmosphere of 1-2 $\mathrm{kPa} \mathrm{O}_{2}$ plus $15-20 \mathrm{kPa} \mathrm{CO}_{2}$ and balance $\mathrm{N}_{2}$ extends the shelf life of shredded Galega kale to 4-5 days at $20^{\circ} \mathrm{C}$, compared with 2-3 days in air storage. Predictive models of chlorophyll $a$ and $b$ degradation as a function of time and gas composition were developed.
\end{abstract}

* Corresponding author. Tel.: +35321 4902383; fax: +353214270249.

E-mail address: faroliveira@ucc.ie (F.A.R. Oliveira).

\section{Introduction}

Controlled and modified atmosphere (CA and MA) storage utilizing low $\mathrm{O}_{2}$ and high $\mathrm{CO}_{2}$ partial pressures are known to maintain quality and consequently extend shelf life of many fresh fruit and vegetables 
(Isenberg, 1979; Smock, 1979; Brecht, 1980; Kader, 1986; Ballantyne et al., 1988; Solomos and Kanellis, 1989; Zagory and Kader, 1989; Qi and Watada, 1997; Kader and Saltveit, 2002a). The decrease of the overall metabolic activity of plant tissues, including a decrease of respiration rate and inhibition of ethylene biosynthesis and action, are the main metabolic responses to reduced $\mathrm{O}_{2}$ and elevated $\mathrm{CO}_{2}$ atmospheres. The beneficial effects on product quality include: (i) delayed ripening and senescence, (ii) reduced incidence and severity of certain physiological disorders, (iii) reduced fungal growth, (iv) greater chlorophyll retention, (v) inhibited sprouting and flower opening, (vi) delayed fruit softening, (vii) delayed toughening in vegetables, (viii) reduced susceptibility to decay, and (ix) control of insect pests. Harmful effects may also occur if the partial pressures of $\mathrm{O}_{2}$ and $\mathrm{CO}_{2}$ are not within the range tolerated by the commodity. Exposure to $\mathrm{O}_{2}$ partial pressures below the tolerance limit may result in anaerobiosis, tissue necrosis, and growth of anaerobic microorganisms (Kader et al., 1989). The latter may include species that constitute serious health hazards for humans if the produce is consumed (Brackett, 1994). Partial pressures of $\mathrm{CO}_{2}$ higher than the tolerance limit may also induce anaerobiosis and tissue injury (Kader and Saltveit, 2002b).

Different fruit and vegetables have unique tolerance limits to low $\mathrm{O}_{2}$ and high $\mathrm{CO}_{2}$. The tolerance limits vary by commodity, cultivar, and physiological age, possibly due to differences in resistance to gas diffusion, as well as for different temperatures and times of exposure (Kader, 1989; Kader et al., 1989; Beaudry and Gran, 1993; Gran and Beaudry, 1993). Therefore, the ranges of $\mathrm{O}_{2}$ and $\mathrm{CO}_{2}$ partial pressures must be defined for each product and for each handling process applied (chopped, shredded or otherwise prepared).

Modified atmosphere packaging (MAP) is a commercial application of low $\mathrm{O}_{2}$ and high $\mathrm{CO}_{2}$ atmospheres. In order to design a successful MAP system, it is important to define the partial pressures of $\mathrm{O}_{2}$ and $\mathrm{CO}_{2}$ that prolong the shelf life of the fresh produce. No research has yet demonstrated a beneficial effect of reduced $\mathrm{O}_{2}$ and elevated $\mathrm{CO}_{2}$ on fresh shredded Galega kale (Brassica oleracea var. acephala DC.) quality. This is an important fresh-cut vegetable in the Portuguese market, which is still quite unexploited by the food industry, distributors, and retailers. The thinly shredded leaves are an ingredient in a traditional soup.
The shredded Galega kale is commonly prepared at the retail level prior to display for sale; however, the shelf life at ambient store temperatures is very short, typically 1 day or less. Thus, development of MAP for shredded Galega kale could substantially improve the quality of the product that is available to consumers. Additionally, MAP could allow preparation of shredded Galega kale to be carried out at central distribution facilities, with associated reductions in the cost of processing.

The objectives of this work were: (i) to evaluate the tolerance to low $\mathrm{O}_{2}$, (ii) to evaluate the tolerance to high $\mathrm{CO}_{2}$, and (iii) to identify the best combination of $\mathrm{O}_{2}$ and $\mathrm{CO}_{2}$ partial pressures for preservation of shredded Galega kale in MAP.

\section{Materials and methods}

\section{Plant material and handling treatment}

Galega kale plants were grown at the Horticultural Research Unit of the University of Florida, Gainesville, Florida, USA. Galega kale is a nonheading leafy cole crop with long petioles and large midribbed leaves. Fully expanded leaves were picked early in the morning and transported immediately to the laboratory. Older, diseased, and injured leaves were discarded. Midribs were excised with a sharp knife, the leaves were then rinsed with potable water to remove dirt and insects, shredded in a hand shredder machine $(1.5 \mathrm{~mm}$ wide slices $)$, rinsed with chlorinated water $\left(100 \mathrm{mg} \mathrm{kg}^{-1} ; \mathrm{pH}\right.$ 7) for $30 \mathrm{~s}$, and centrifuged in a salad spinner to remove adhering water. Approximately $150 \mathrm{~g}$ of shredded kale per replicate were placed in glass jars of $1.7 \mathrm{dm}^{3}$ capacity in a controlled temperature room. The jar lids had a rubber septum for gas sampling and two rubber tubes for gas application. A tube was extended from the inlet to the bottom of the jar to facilitate uniform flushing of the gas mixture. For each atmosphere treatment, a flowboard was connected to six jars in order to deliver a constant and equal gas flow rate. The gas flow rate to each jar was $1.7 \mathrm{ml} \mathrm{s}^{-1}$. The flowboard was connected to a gas mixing board inside the room, which delivered the specified partial pressures of $\mathrm{O}_{2}, \mathrm{CO}_{2}$, and $\mathrm{N}_{2}$. The error in the target partial pressure was 0.6 and $0.2 \mathrm{kPa}$ for $\mathrm{O}_{2}$ and $\mathrm{CO}_{2}$, respectively. Gas streams were humidified by bubbling them through deionized 
water in jars, in order to avoid weight loss of the product.

\section{Experimental design}

Sets of six jars were stored at $20 \pm 0.5^{\circ} \mathrm{C}$ and flushed with different atmospheres under the following experimental design (total pressure was $101 \mathrm{kPa}$ ):

(i) Low $\mathrm{O}_{2}$ tolerance experiment. Four atmospheres were tested: 1,2 , and $3 \mathrm{kPa} \mathrm{O}$ with the balance being $\mathrm{N}_{2}$, and air as the control.

(ii) High $\mathrm{CO}_{2}$ tolerance experiment. Four atmospheres were tested: 10,15 , and $20 \mathrm{kPa} \mathrm{CO}_{2}$ plus $21 \mathrm{kPa} \mathrm{O}_{2}$ with the balance being $\mathrm{N}_{2}$, and air as the control.

(iii) Low $\mathrm{O}_{2}$ plus high $\mathrm{CO}_{2}$ experiment. Five atmospheres were tested: all the combinations of 1 or $2 \mathrm{kPa} \mathrm{O}_{2}$ plus 15 or $20 \mathrm{kPaCO}_{2}$ with the balance being $\mathrm{N}_{2}$, and air as the control.

Physiological, sensory, and physicochemical parameters were monitored during the experiments. Storage was terminated as the shredded kale deteriorated. Respiration rates were determined every day during the course of each experiment for each storage atmosphere. In addition, every day one jar from each storage atmosphere was opened, the shredded kale weighed, its sensory attributes immediately evaluated and its colour instrumentally measured. Samples for water content, chlorophyll (Chl), and ascorbic acid (AA) determinations were taken. The $\mathrm{Chl}$ and AA samples were frozen and stored at $-25^{\circ} \mathrm{C}$ prior to analysis.

\section{Respiration rate}

Respiration rate was determined using a closed system. The gas flow was halted, the gas stream inlets and outlets closed, and two gas samples of $0.5 \mathrm{ml}$ were withdrawn from each of three jars per treatment with $1.0 \mathrm{ml}$ plastic syringes, at time zero and after specified time intervals. Gas samples were analysed with a Gow-Mac Series 580 gas chromatograph (Bridgewater, NJ, USA). The gas chromatograph was equipped with two columns in series and a thermal conductivity detector. One column was a porous polymer column (80-100 mesh Columpak PQ) and the other was a molecular sieve 5A column (60-80 mesh). The gas carrier was helium at $275 \mathrm{kPa}$, flow rate $0.5 \mathrm{ml} \mathrm{s}^{-1}$. Tem- perature of both columns was set at $44{ }^{\circ} \mathrm{C}$ with the injector and detector at $90^{\circ} \mathrm{C}$. Calibration of the gas chromatograph was performed using a calibration mixture of $7.13 \mathrm{kPaO} \mathrm{O}_{2}$ plus $7.12 \mathrm{kPa} \mathrm{CO} \mathrm{CO}_{2} \mathrm{O}_{2}$ and $\mathrm{CO}_{2}$ production rates $\left(\mathrm{mg} \mathrm{kg}^{-1} \mathrm{~s}^{-1}\right)$ were determined by Eqs. (1) and (2):

$$
\begin{aligned}
R_{\mathrm{O}_{2}} & =\frac{\left(p_{\mathrm{O}_{2}}^{\mathrm{i}}-p_{\mathrm{O}_{2}}^{\mathrm{f}}\right) \times V_{\mathrm{f}} \times W_{\mathrm{O}_{2}}}{10^{3} \times R \times T \times M\left(t_{\mathrm{f}}-t_{\mathrm{i}}\right)} \\
R_{\mathrm{CO}_{2}} & =\frac{\left(p_{\mathrm{CO}_{2}}^{\mathrm{f}}-p_{\mathrm{CO}_{2}}^{\mathrm{i}}\right) \times V_{\mathrm{f}} \times W_{\mathrm{CO}_{2}}}{10^{3} \times R \times T \times M\left(t_{\mathrm{f}}-t_{\mathrm{i}}\right)}
\end{aligned}
$$

where $p_{\mathrm{O}_{2}}^{\mathrm{i}}$ and $p_{\mathrm{CO}_{2}}^{\mathrm{i}}$ are the $\mathrm{O}_{2}$ and $\mathrm{CO}_{2}$ partial pressures at initial time in $\mathrm{Pa}, p_{\mathrm{O}_{2}}^{\mathrm{f}}$ and $p_{\mathrm{CO}_{2}}^{\mathrm{f}}$ the $\mathrm{O}_{2}$ and $\mathrm{CO}_{2}$ partial pressures at final time in $\mathrm{Pa}, W_{\mathrm{O}_{2}}$ and $W_{\mathrm{CO}_{2}}$ the molecular weights of $\mathrm{O}_{2}$ and $\mathrm{CO}_{2}$ in $\mathrm{kg} \mathrm{mol}^{-1}, R$ the universal gas constant in $\mathrm{m}^{3} \mathrm{~Pa} \mathrm{~mol}^{-1} \mathrm{~K}^{-1}, T$ the temperature in $\mathrm{K}, M$ the product mass in $\mathrm{kg}, t_{\mathrm{f}}-t_{\mathrm{i}}$ the time interval in $\mathrm{s}$ and $V_{\mathrm{f}}$ is the free volume inside the jar in 1 .

\section{Sensory inspection}

The sensory attributes (off-odour, colour and overall visual quality), which were selected based on the consumer point of view, were evaluated using a 1-9 rating scale index, with 1 being the lowest and 9 the highest levels of the analysed attribute. The evaluations were blind (i.e., the jars could not be identified). Visual quality evaluation included general appearance, colour, wilting, and detectable injuries. The limit of saleability was defined as the level 5 of the scale. Shelf life of the product was calculated as the time when the first sensory attribute reached the score corresponding to the limit of saleability. When necessary, shelf life was calculated by polynomial interpolation between sampling times.

\section{Colour measurement}

Colour was measured with a Minolta CR-200 Chromameter (Ramsey, NJ, USA). The measuring head was placed against the top surface of the shredded leaves. Six measurements were performed per storage atmosphere in order to compensate for the great variability due to the non-uniform surface. The $L^{*}, a^{*}$, and $b^{*}$ from the colour notation system were displayed and $\Delta E$ was 
determined (Eq. (3)). The $L^{*}$ value indicates lightness, $a^{*}$ indicates chromaticity on a green $(-)$ to red $(+)$ axis, and $b^{*}$ represents chromaticity on a blue $(-)$ to yellow $(+)$ axis. The $\Delta E$ value is an overall measure of the differences in $L^{*}, a^{*}$, and $b^{*}$ values compared to the respective initial values $\left(L_{\mathrm{i}}^{*}, a_{\mathrm{i}}^{*}, b_{\mathrm{i}}^{*}\right)$.

$$
\Delta E=\left[\left(L^{*}-L_{\mathrm{i}}^{*}\right)^{2}+\left(a^{*}-a_{\mathrm{i}}^{*}\right)^{2}+\left(b^{*}-b_{\mathrm{i}}^{*}\right)^{2}\right]^{1 / 2}
$$

\section{Water content}

Three replicates per storage atmosphere of approximately $2 \mathrm{~g}$ were dried at $70^{\circ} \mathrm{C}$. The samples were reweighed periodically until no significant changes were detected (usually 1 day), and the water content was determined by mass balance.

\section{Chlorophyll content}

The sample preparation for $\mathrm{Chl}$ determination consisted of mixing approximately $0.2 \mathrm{~g}$ of shredded leaves with $10 \mathrm{ml}$ of $N, N$-dimethylformamide. Three replicates were performed per storage atmosphere. The samples were stored at $5{ }^{\circ} \mathrm{C}$ for $36 \mathrm{~h}$ in darkness (covered with aluminium foil) then shaken for $24 \mathrm{~h}$. For the $\mathrm{Chl}$ analysis, the solution was filtered through Miracloth (Calbiochem, San Diego, CA, USA) and the absorbance measured at 647 and $664 \mathrm{~nm}$. The Chl concentrations were calculated using the equations developed by Moran (1982):

$$
\begin{aligned}
\text { Chl } a= & \left(12.64 \times A_{664}-2.99 \times A_{647}\right) \\
& \times \frac{1000 \times V_{\text {sample }}}{M}
\end{aligned}
$$

$$
\begin{aligned}
\text { Chl } b= & \left(-5.6 \times A_{664}+23.26 \times A_{647}\right) \\
& \times \frac{1000 \times V_{\text {sample }}}{M}
\end{aligned}
$$

where Chl $a$ and Chl $b$ represents chlorophyll $a$ and $b$ content in $\mathrm{mg} \mathrm{kg}^{-1}$ of fresh weight (FW), respectively, $A_{647}$ and $A_{664}$ the absorbance at 647 and $664 \mathrm{~nm}$, respectively, $V_{\text {sample }}$ the sample volume in $\mathrm{ml}$, and $M$ the sample mass in $\mathrm{kg}$. The $\mathrm{Chl}$ content was determined based on the fresh weight of the product be- cause weight loss was considered negligible, being less than $3 \%$.

\section{Adcorbic acid content}

The dinitrophenylhydrazine (DNPH) method developed by Terada et al. (1978) was used for total AA analysis. Two replicates were performed per storage atmosphere. Tissue samples weighing approximately $0.8 \mathrm{~g}$ were mixed with $40 \mathrm{ml}$ of a mixture of $6 \%$ metaphosphoric acid in $2 \mathrm{~N}$ acetic acid. The mixture was centrifuged $\left(20 \mathrm{~min}\right.$ at $\left.17,600 \times g_{n}\right)$ and the supernatant clarified by filtration through Whatman \#4 filter paper. The supernatant was thawed at room temperature $\left(23-25^{\circ} \mathrm{C}\right)$. A $1-\mathrm{ml}$ aliquot of the supernatant was mixed with one drop of $0.2 \% 2$,6dichlorophenolindolphenol and the solution was incubated at room temperature for $1 \mathrm{~h}$, then $1 \mathrm{ml}$ of $2 \%$ thiourea in $5 \%$ metaphosphoric acid and $0.5 \mathrm{ml}$ of $2 \%$ DNPH in 9N sulfuric acid were added, followed by incubation at $60^{\circ} \mathrm{C}$ for $3 \mathrm{~h}$. The reaction was stopped by placing the tubes in an ice bath and slowly adding $2.5 \mathrm{ml}$ of ice cold $90 \%$ sulfuric acid. Finally, absorbance at $540 \mathrm{~nm}$ was read against a blank and the AA concentration determined using a standard curve. The sample concentration of AA was calculated per $\mathrm{kg}$ of $\mathrm{FW}$ :

$\mathrm{AA}=\frac{C_{\text {sample }} \times V_{\text {sample }}}{M}$

where AA is the ascorbic acid content in $\mathrm{mg} \mathrm{kg}^{-1}$, $C_{\text {sample }}$ the sample AA concentration in $\mathrm{mg}^{-1}, V_{\text {sample }}$ the sample volume in 1 , and $M$ is the sample mass in $\mathrm{kg}$.

\section{Statistical analysis}

A two factor with replication analysis of variance (ANOVA) at a significance level of 5\% and the least square difference (LSD) test were applied to the data using the Statistica software (release 5.1, 97 edition, Statsoft Inc., Tulsa, OK, USA). Degradation of the Chl $a$ and $b$ were both modelled by the Weibull model (Weibull, 1951; Seber and Wild, 1989). The model parameters were estimated by fitting the model to the experimental data by non-linear regression using the same software. 


\section{Results and discussion}

\section{Tolerance to low $\mathrm{O}_{2}$}

A higher metabolic activity of the product is manifested by a higher rate of respiration. Thus, there is a direct relation between the rate of deterioration of the product and the respiration rate. There was a clear difference between respiration rate of shredded kale stored in air and that stored in low $\mathrm{O}_{2}$ atmospheres (Fig. 1). Samples stored in air had the highest $\mathrm{CO}_{2}$ production rate, on average $4.7 \mathrm{mg} \mathrm{kg}^{-1} \mathrm{~s}^{-1}$, and those stored in $1 \mathrm{kPa} \mathrm{O}_{2}$ had the lowest $\mathrm{CO}_{2}$ production rate, on average $1.5 \mathrm{mg} \mathrm{kg}^{-1} \mathrm{~s}^{-1}$. The respiration rate of shredded kale exposed to air increased during storage, probably due to a fast degradation of the product in this atmosphere. If $\mathrm{O}_{2}$ falls below a critical partial pressure, anaerobic respiration is induced. Fermentative respiration is characterised by production of ethanol, acetaldehyde, and $\mathrm{CO}_{2}$ without $\mathrm{O}_{2}$ consumption. No significant increase in RQ values, the ratio between $\mathrm{CO}_{2}$ production and $\mathrm{O}_{2}$ consumption rates, was observed in any of the low $\mathrm{O}_{2}$ atmospheres (data not shown). This indicates that sufficient $\mathrm{O}_{2}$ was available for aerobic respiration and no anaerobic respiration was induced.

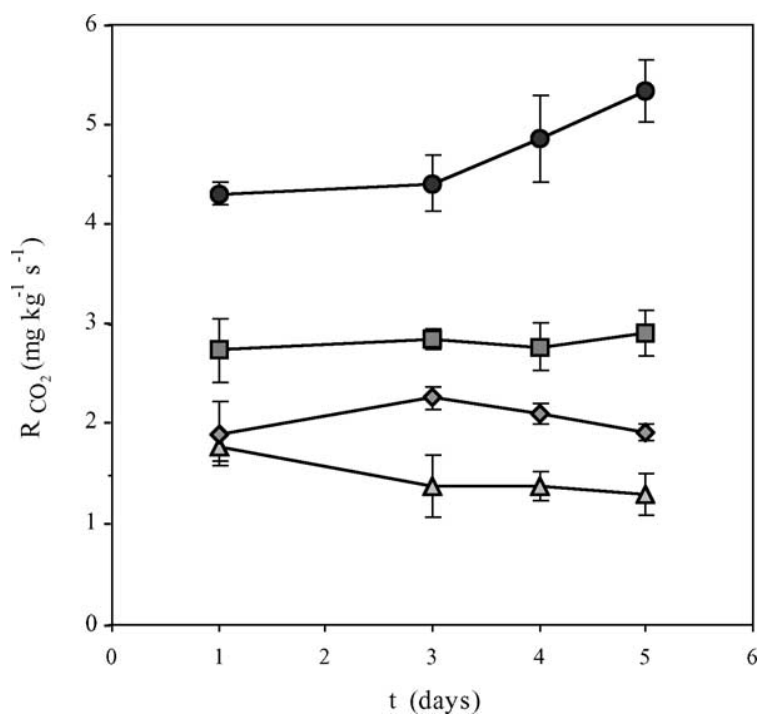

Fig. 1. $\mathrm{CO}_{2}$ production rate of shredded Galega kale stored in air $(\circlearrowleft), 3 \mathrm{kPa} \mathrm{O}_{2}(\square), 2 \mathrm{kPa} \mathrm{O}_{2}(\diamond)$ or $1 \mathrm{kPa} \mathrm{O}_{2}(\triangle)$ at $20^{\circ} \mathrm{C}$ (average of three replicates \pm S.D.).
Table 1

Sensory attributes of shredded Galega kale stored in low $\mathrm{O}_{2}$ atmospheres and in air at $20^{\circ} \mathrm{C}$

\begin{tabular}{|c|c|c|c|c|c|}
\hline \multirow{2}{*}{$\begin{array}{l}\text { Sensory } \\
\text { attributes }\end{array}$} & \multirow[t]{2}{*}{$t$ (days) } & \multicolumn{4}{|c|}{ Storage atmosphere } \\
\hline & & $1 \mathrm{kPa} \mathrm{O} 2$ & $2 \mathrm{kPa} \mathrm{O}_{2}$ & $3 \mathrm{kPa} \mathrm{O}_{2}$ & Air \\
\hline \multirow[t]{7}{*}{ Off-odour } & 0 & 1 & 1 & 1 & 1 \\
\hline & 1 & 1 & 1 & 1 & 1 \\
\hline & 2 & 1 & 2 & 2 & 3 \\
\hline & 3 & 2 & 2 & 2 & 5 \\
\hline & 4 & 4 & 4 & 4 & 6 \\
\hline & 5 & 7 & 7 & 7 & 9 \\
\hline & 6 & 9 & 9 & 9 & - \\
\hline \multirow[t]{7}{*}{ Colour } & 0 & 9 & 9 & 9 & 9 \\
\hline & 1 & 8 & 9 & 9 & 8 \\
\hline & 2 & 6 & 7 & 6 & 5 \\
\hline & 3 & 7 & 6 & 6 & 3 \\
\hline & 4 & 7 & 6 & 4 & 1 \\
\hline & 5 & 5 & 4 & 3 & 1 \\
\hline & 6 & 4 & 2 & 1 & - \\
\hline \multirow[t]{7}{*}{ Visual quality } & 0 & 9 & 9 & 9 & 9 \\
\hline & 1 & 8 & 9 & 9 & 8 \\
\hline & 2 & 6 & 7 & 6 & 5 \\
\hline & 3 & 7 & 6 & 6 & 2 \\
\hline & 4 & 6 & 5 & 4 & 1 \\
\hline & 5 & 5 & 4 & 3 & 1 \\
\hline & 6 & 4 & 2 & 1 & - \\
\hline
\end{tabular}

The values show the rating in a $1-9$ scale index.

Shredded Galega kale exposed to low $\mathrm{O}_{2}$ partial pressures maintained its sensory quality longer than shredded kale exposed to ambient air (Table 1). Low $\mathrm{O}_{2}$ atmosphere extended the shelf life of shredded Galega kale from $2 \mathrm{~d}$ in air to $3.5 \mathrm{~d}$ in $3 \mathrm{kPa} \mathrm{O}, 4 \mathrm{~d}$ in $2 \mathrm{kPa}$ $\mathrm{O}_{2}$ and $4.5 \mathrm{~d}$ in $1 \mathrm{kPa} \mathrm{O} \mathrm{O}_{2}$. For samples stored in air or $3 \mathrm{kPa} \mathrm{O}_{2}$, shelf life was controlled by colour (i.e., yellowing) and visual quality, for samples stored in $2 \mathrm{kPa}$ $\mathrm{O}_{2}$ the limiting sensory attribute was visual quality, and for samples stored in $1 \mathrm{kPa} \mathrm{O}_{2}$ off-odours above acceptable levels defined the product shelf life. Low $\mathrm{O}_{2}$ atmospheres were particularly effective in decreasing the rate of colour changes. Indeed, yellowing was much faster in air than in low $\mathrm{O}_{2}$ atmospheres (Fig. 2). Colour was unacceptable after $2 \mathrm{~d}$ in air, whereas in 1 , 2 , and $3 \mathrm{kPaO}_{2}$ it took 5, 4.5, and $3.5 \mathrm{~d}$, respectively, to reach colour scores of 5. Changes in visual quality were very similar to those for colour, with the exception that in $2 \mathrm{kPaO}_{2}$ the limit of acceptability was reached in $4 \mathrm{~d}$. Off-odours were first noticeable after $3 \mathrm{~d}$ in the $1 \mathrm{kPa}$ $\mathrm{O}_{2}$ atmosphere. Kale stored in other atmospheres first 


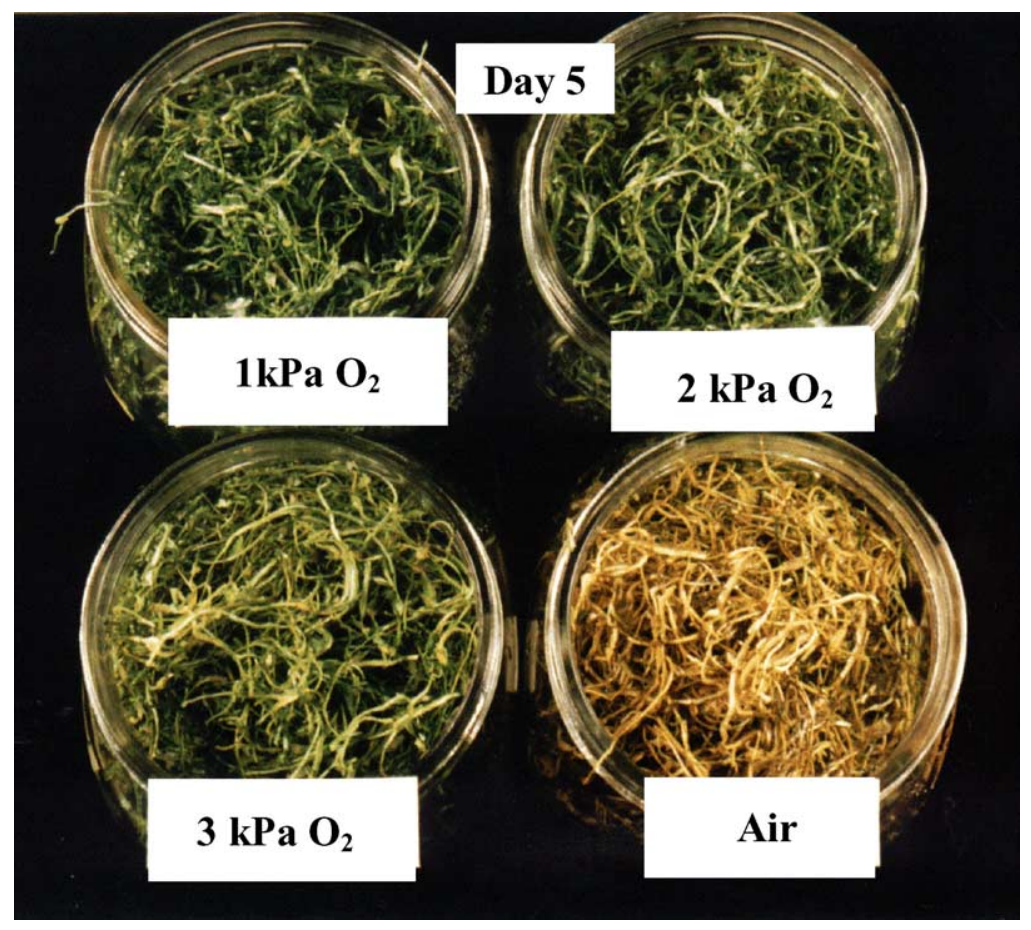

Fig. 2. Shredded Galega kale stored $5 \mathrm{~d}$ in low $\mathrm{O}_{2}$ atmospheres or in air at $20^{\circ} \mathrm{C}$.

developed detectable off-odours after $2 \mathrm{~d}$ storage, most noticeably in air storage. Unacceptable off-odours occurred after $4.5 \mathrm{~d}$ for all the low $\mathrm{O}_{2}$ atmospheres, and after $3 \mathrm{~d}$ in air.

Colour is one of the most important visual attributes in food products. If the appearance is unattractive, a potential consumer will never experience the other major attributes-flavour, texture, and odour. The narrow shreds as well as the differences in colour between ribs and leaves were a great limitation in identifying colour differences between samples stored in different atmospheres. Nevertheless, after 2 or $3 \mathrm{~d}$ of storage, samples stored in air showed significantly greater values of all the colour parameters $\left(L^{*}, a^{*}, b^{*}\right.$, and $\left.\Delta E\right)$ than samples stored in low $\mathrm{O}_{2}$ atmospheres (Table 2). Increased $L^{*}$ and $b^{*}$ values indicate lightening and yellowing, respectively, while increased $a^{*}$ values indicate loss of greenness. $L^{*}, a^{*}, b^{*}$, and $\Delta E$ values increased during storage in air, showing a faster lightening and yellowing of the product in these conditions. Colour values changed relatively little in low $\mathrm{O}_{2}$ atmospheres, except for the value of $b^{*}$ in samples stored in $3 \mathrm{kPa} \mathrm{O}$ after
$5 \mathrm{~d}$ of storage, which was significantly greater than for shorter storage times. This result agrees with the ratings observed for sensory analysis of colour (Table 1). No colour differences between the three low $\mathrm{O}_{2}$ partial pressures could be detected.

Water content varied between 858 and $887 \mathrm{~g} \mathrm{~kg}^{-1}$, averaging $870 \pm 7 \mathrm{~g} \mathrm{~kg}^{-1}$, and no clear relationship was found with storage atmosphere or storage time. Greenness, an indicator of product quality, is the result of the Chl content. As Chl degrades during senescence, the green leaves become yellow and brown. In green vegetables, chlorophyll $a$ and $b$ are the most important pigments (Khachik et al., 1986; Gross, 1991). There was no visible degradation of $\mathrm{Chl}$ content in samples stored in $1 \mathrm{kPa} \mathrm{O}_{2}$, and samples stored in the other low $\mathrm{O}_{2}$ atmospheres showed a much slower degradation of chlorophyll than samples stored in air (Fig. 3). Retardation of $\mathrm{Chl}$ degradation was considered by Gross (1991) to be one of the most beneficial effects of low $\mathrm{O}_{2}$ and high $\mathrm{CO}_{2}$ on green vegetables. The mechanism of $\mathrm{Chl}$ breakdown during leaf senescence is not fully understood (Matile et al., 1996). The ratio of Chl $a$ to $b$ 
Table 2

Colour parameters and ascorbic acid content of shredded Galega kale stored in low $\mathrm{O}_{2}$ atmospheres and in air at $20^{\circ} \mathrm{C}$ (average \pm S.D.)

\begin{tabular}{|c|c|c|c|c|c|}
\hline \multirow[t]{2}{*}{ Physicochemical parameters } & \multirow[t]{2}{*}{$t$ (days) } & \multicolumn{4}{|c|}{ Storage atmosphere } \\
\hline & & $1 \mathrm{kPa} \mathrm{O} 2$ & $2 \mathrm{kPa} \mathrm{O}_{2}$ & $3 \mathrm{kPa} \mathrm{O} 2$ & Air \\
\hline$L^{*} \pm$ S.D. & $\begin{array}{l}0 \\
1 \\
2 \\
3 \\
4 \\
5 \\
6\end{array}$ & $\begin{array}{c}- \\
37 \pm 3 \\
36 \pm 2 \\
31 \pm 2 \\
35 \pm 3 \\
36 \pm 3 \\
36 \pm 2\end{array}$ & $\begin{array}{c}- \\
36 \pm 2 \\
35 \pm 5 \\
35 \pm 4 \\
30 \pm 3 \\
34 \pm 3 \\
39 \pm 3\end{array}$ & $\begin{array}{l}- \\
33 \pm 4 \\
34 \pm 4 \\
35 \pm 4 \\
34 \pm 2 \\
37 \pm 1 \\
39 \pm 3\end{array}$ & $\begin{array}{c}35 \pm 3 \\
35 \pm 3 \\
38 \pm 4 \\
39 \pm 2 \\
43 \pm 3 \\
43 \pm 3 \\
-\end{array}$ \\
\hline$a^{*} \pm$ S.D. & $\begin{array}{l}0 \\
1 \\
2 \\
3 \\
4 \\
5 \\
6\end{array}$ & $\begin{array}{c}- \\
-14 \pm 2 \\
-13 \pm 2 \\
-12 \pm 2 \\
-13 \pm 1 \\
-13 \pm 1 \\
-12 \pm 1\end{array}$ & $\begin{array}{c}- \\
-14 \pm 2 \\
-12 \pm 1 \\
-13 \pm 1 \\
-12 \pm 1 \\
-11 \pm 1 \\
-10 \pm 2\end{array}$ & $\begin{array}{c}- \\
-15 \pm 1 \\
-13 \pm 1 \\
-13 \pm 1 \\
-12 \pm 1 \\
-13 \pm 1 \\
-10 \pm 1\end{array}$ & $\begin{array}{c}-15 \pm 1 \\
-14 \pm 1 \\
-13 \pm 1 \\
-13 \pm 1 \\
-8 \pm 1 \\
-5 \pm 1 \\
-\end{array}$ \\
\hline$b^{*} \pm$ S.D. & $\begin{array}{l}0 \\
1 \\
2 \\
3 \\
4 \\
5 \\
6\end{array}$ & $\begin{array}{c}- \\
19 \pm 2 \\
19 \pm 2 \\
17 \pm 3 \\
19 \pm 3 \\
19 \pm 2 \\
19 \pm 3\end{array}$ & $\begin{array}{c}- \\
18 \pm 3 \\
17 \pm 1 \\
19 \pm 2 \\
18 \pm 1 \\
19 \pm 2 \\
21 \pm 2\end{array}$ & $\begin{array}{c}- \\
21 \pm 2 \\
18 \pm 1 \\
18 \pm 2 \\
18 \pm 2 \\
23 \pm 2 \\
25 \pm 2\end{array}$ & $\begin{array}{l}20 \pm 2 \\
21 \pm 1 \\
20 \pm 2 \\
23 \pm 2 \\
25 \pm 2 \\
26 \pm 3 \\
-\end{array}$ \\
\hline$\Delta E \mathrm{~S} . \mathrm{D}$ & $\begin{array}{l}1 \\
2 \\
3 \\
4 \\
5 \\
6\end{array}$ & $\begin{array}{l}4 \pm 2 \\
3 \pm 3 \\
5 \pm 2 \\
4 \pm 2 \\
4 \pm 2 \\
4 \pm 1\end{array}$ & $\begin{array}{l}4 \pm 2 \\
6 \pm 1 \\
5 \pm 2 \\
6 \pm 2 \\
5 \pm 2 \\
7 \pm 3\end{array}$ & $\begin{array}{l}3 \pm 2 \\
4 \pm 1 \\
4 \pm 2 \\
4 \pm 2 \\
5 \pm 1 \\
9 \pm 1\end{array}$ & $\begin{array}{r}3 \pm 1 \\
5 \pm 2 \\
5 \pm 3 \\
12 \pm 2 \\
15 \pm 4 \\
-\end{array}$ \\
\hline $\mathrm{AA} \pm$ S.D. $\left(\mathrm{mg} \mathrm{kg}^{-1}\right)$ & $\begin{array}{l}0 \\
1 \\
2 \\
3 \\
4 \\
5\end{array}$ & $\begin{array}{c}- \\
524 \pm 26 \\
418 \pm 27 \\
593 \pm 30 \\
438 \pm 62 \\
463 \pm 15\end{array}$ & $\begin{array}{c}- \\
512 \pm 30 \\
412 \pm 78 \\
501 \pm 19 \\
379 \pm 23 \\
354 \pm 39\end{array}$ & $\begin{array}{l}\quad- \\
472 \pm 126 \\
450 \pm 8 \\
515 \pm 35 \\
490 \pm 4 \\
387 \pm 19\end{array}$ & $\begin{array}{l}513 \pm 19 \\
538 \pm 42 \\
534 \pm 42 \\
372 \pm 4 \\
317 \pm 11 \\
202 \pm 23\end{array}$ \\
\hline
\end{tabular}

is usually around 3:1 (Gross, 1991). The experimental ratio ranged from 2.2:1 to 3.5:1. The ratio of $\mathrm{Chl} a$ to $b$ in the air control was much lower after $5 \mathrm{~d}$ of storage when compared with samples stored for shorter times, indicating that $\mathrm{Chl} a$ degraded faster than $\mathrm{Chl} b$. No differences in $\mathrm{Chl} a$ to $b$ ratios were observed among the low $\mathrm{O}_{2}$ atmospheres.

Ascorbic acid is a cofactor in numerous enzymatic reactions and an important nutritional component of fruit and vegetables. It is very labile and its preservation is of crucial importance to the human diet (Ezell and Wilcox, 1959). Degradation of AA was faster in air than in the low $\mathrm{O}_{2}$ atmospheres, particularly after $2 \mathrm{~d}$ of storage (Table 2), while little difference was observed between 1,2 , and $3 \mathrm{kPa} \mathrm{O}$. Zagory and Kader (1989) pointed out that low $\mathrm{O}_{2}$ atmospheres slow AA loss by inhibiting its oxidation, Barth et al. (1993) reported higher AA retention in broccoli stored in MAP than in unpacked broccoli, and Ahvenainen (1996) reported that losses of AA and carotenes are the main factors limiting nutritional quality of fresh-cut vegetables. Ezell and Wilcox (1959) concluded that the loss of AA in kale is a function of storage temperature and wilting. 

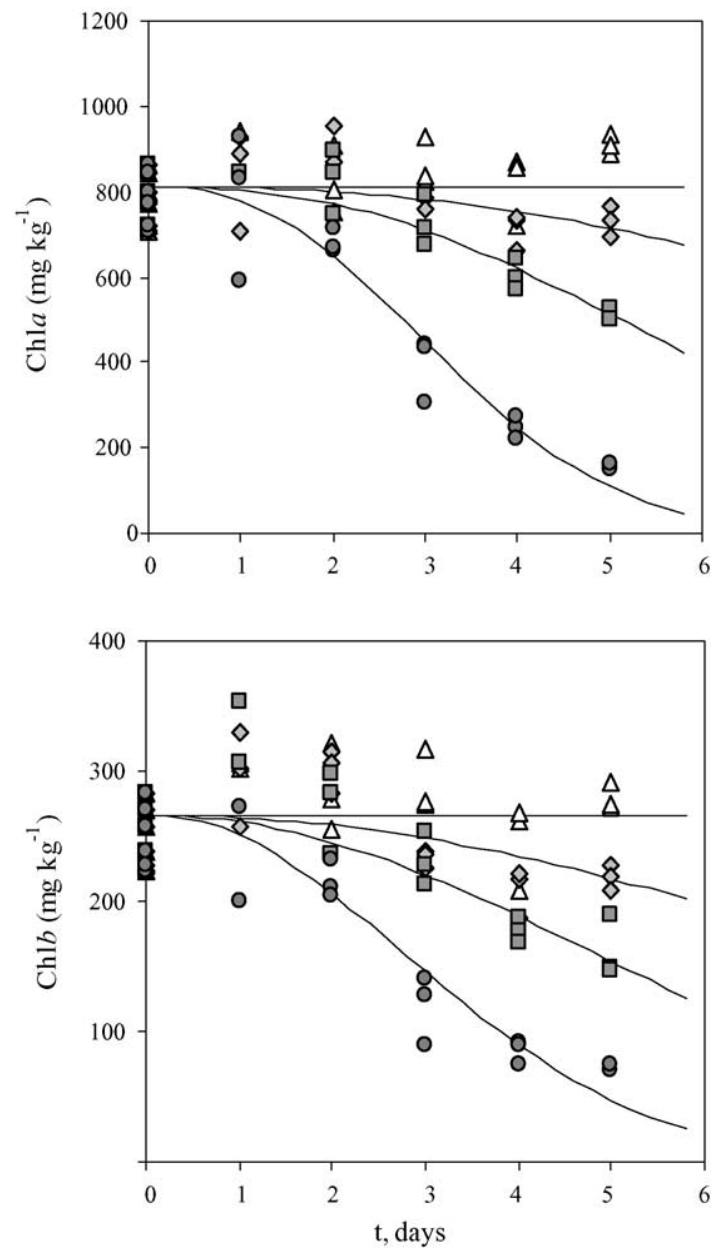

Fig. 3. Chlorophyll $a$ and $b$ degradation in shredded Galega kale stored in air $(\bullet), 3 \mathrm{kPa} \mathrm{O}_{2}(\square), 2 \mathrm{kPa} \mathrm{O}_{2}(\diamond)$ or $1 \mathrm{kPa} \mathrm{O}(\triangle)$ at $20^{\circ} \mathrm{C}$. The lines are the model fit (Eqs. (7) and (8)).

\section{Tolerance to high $\mathrm{CO}_{2}$}

There was a clear difference in $\mathrm{CO}_{2}$ production rates between the different $\mathrm{CO}_{2}$ atmospheres (Fig. 4). The $\mathrm{CO}_{2}$ production rate was greater in samples stored in air when compared with samples stored in high $\mathrm{CO}_{2}$ atmospheres. Increasing $\mathrm{CO}_{2}$ partial pressures from 10 to $15 \mathrm{kPa}$ decreased $\mathrm{CO}_{2}$ production to a rate similar to that for $20 \mathrm{kPa} . \mathrm{CO}_{2}$ production rates of samples stored in air increased over time and this effect also occurred in samples stored in high $\mathrm{CO}_{2}$ partial pressures from the second day of storage. There was no significant effect of $\mathrm{CO}_{2}$ partial pressures on RQ (data not shown).

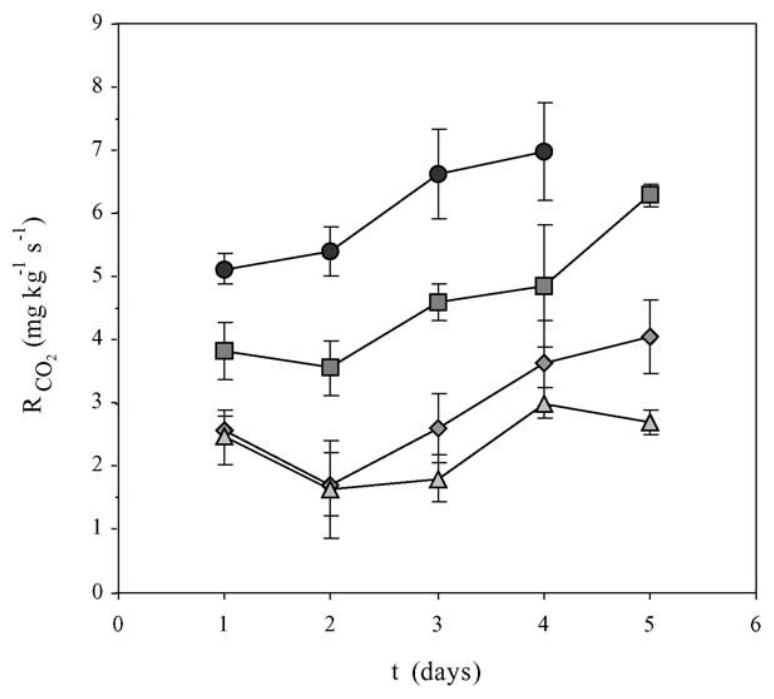

Fig. 4. $\mathrm{CO}_{2}$ production rate of shredded Galega kale stored in air $(\circlearrowleft), 10 \mathrm{kPa} \mathrm{CO}_{2}(\square), 15 \mathrm{kPa} \mathrm{CO}_{2}(\diamond)$ or $20 \mathrm{kPa} \mathrm{CO}_{2}(\triangle)$ at $20^{\circ} \mathrm{C}$ (average of three replicates \pm S.D.).

Shredded Galega kale stored in high $\mathrm{CO}_{2}$ atmospheres maintained sensory quality longer than samples stored in air (Table 3). The high $\mathrm{CO}_{2}$ contents increased product shelf life from $2.2 \mathrm{~d}$ in air to $3.5 \mathrm{~d}$ in $20 \mathrm{kPaCO}_{2}$. Thus, high $\mathrm{CO}_{2}$ partial pressures are not as effective as low $\mathrm{O}_{2}$ partial pressures in extending shelf life (in the ranges tested). Colour and visual quality were the critical factors limiting shelf life in all conditions tested. Differences among samples stored in high $\mathrm{CO}_{2}$ partial pressures could only be detected shortly before or after the limit of saleability was reached. Samples stored in $20 \mathrm{kPa} \mathrm{CO}_{2}$ maintained colour and visual quality better than samples stored in 10 or $15 \mathrm{kPa} \mathrm{CO}_{2}$. Shredded Galega kale stored in high $\mathrm{CO}_{2}$ atmospheres developed off-odour after $3 \mathrm{~d}$ of storage, whereas in samples stored in air off-odour was first detected after $2 \mathrm{~d}$. Unacceptable off-odour was detected after $2.7 \mathrm{~d}$ in samples stored in air, $3 \mathrm{~d}$ in samples stored in $10 \mathrm{kPa}$ $\mathrm{CO}_{2}, 4 \mathrm{~d}$ in samples stored in $15 \mathrm{kPaCO}_{2}$, and $4.3 \mathrm{~d}$ in samples stored in $20 \mathrm{kPa} \mathrm{CO}_{2}$. In contrast to what was observed with low $\mathrm{O}_{2}$ atmospheres, where the samples yellowed with time, in this case browning was observed. One possible reason is that low $\mathrm{O}_{2}$ atmospheres inhibited oxidative browning.

$L^{*}, a^{*}, b^{*}$, and $\Delta E$ values changed in response to high $\mathrm{CO}_{2}$ during storage (Table 4). Samples stored in air for over 1-2 d showed higher values of $L^{*}, a^{*}, b^{*}$, 
Table 3

Sensory attributes of shredded Galega kale stored in high $\mathrm{CO}_{2}$ atmospheres and in air at $20^{\circ} \mathrm{C}$

\begin{tabular}{llllll}
\hline \multirow{2}{*}{$\begin{array}{l}\text { Sensory } \\
\text { attributes }\end{array}$} & $t$ (days) & \multicolumn{4}{l}{ Storage atmospheres } \\
\cline { 3 - 6 } & & Air & $10 \mathrm{kPa}$ & $15 \mathrm{kPa}$ & $20 \mathrm{kPa}$ \\
$\mathrm{CO}_{2}$ & $\mathrm{CO}_{2}$ & $\mathrm{CO}_{2}$ \\
\hline Off-odour & 0 & 1 & 1 & 1 & 1 \\
& 1 & 1 & 1 & 1 & 1 \\
& 2 & 3 & 1 & 1 & 1 \\
& 3 & 6 & 5 & 4 & 4 \\
& 4 & 9 & 6 & 5 & 4 \\
Colour & 5 & - & 9 & 8 & 8 \\
& 0 & 9 & 9 & 9 & 9 \\
& 1 & 8 & 9 & 9 & 9 \\
& 2 & 6 & 8 & 8 & 8 \\
& 3 & 3 & 4 & 6 & 6 \\
Visual quality & 0 & 1 & 2 & 3 & 4 \\
& 4 & - & 1 & 1 & 3 \\
& 5 & 8 & 9 & 9 & 9 \\
& 1 & 6 & 9 & 9 & 9 \\
& 2 & 6 & 8 & 8 & 8 \\
& 3 & 1 & 4 & 6 & 6 \\
& 4 & 1 & 2 & 3 & 4 \\
& 5 & - & 1 & 2 & 3 \\
\hline
\end{tabular}

The values show the rating in a $1-9$ scale index.

and $\Delta E$ than those stored in high $\mathrm{CO}_{2}$ atmospheres. Analysis of variance indicated that parameter $b^{*}$ decreased with time, while $a^{*}$ and $\Delta E$ increased during storage. Water content varied from 862 to $887 \mathrm{~g} \mathrm{~kg}^{-1}$, with an average of $875 \pm 6 \mathrm{~g} \mathrm{~kg}^{-1}$. Degradation of Chl $a$ and $b$ was reduced at high $\mathrm{CO}_{2}$ partial pressures (Fig. 5). This may have been due to decreased cellular $\mathrm{pH}$ in the high $\mathrm{CO}_{2}$ treatments and consequent reduction of the breakdown of $\mathrm{Chl}$ into pheophytin (Zagory and Kader, 1989; Gross, 1991). The ratio of Chl $a$ to $b$ was not statistically different between the high $\mathrm{CO}_{2}$ treatments. This ratio was stable over time for samples stored in high $\mathrm{CO}_{2}$ atmospheres, but decreased on day 4 in samples stored in air. Some AA degradation occurred, but there was no effect of $\mathrm{CO}_{2}$ on AA degradation rate (Table 4).

\section{Combination of low $\mathrm{O}_{2}$ and high $\mathrm{CO}_{2}$}

Tolerance limits for $\mathrm{O}_{2}$ and $\mathrm{CO}_{2}$ may be affected by the partial pressure of the other gas (Kader et al., 1989). Beaudry and Gran (1993) observed increases in the $\mathrm{O}_{2}$ tolerance limit (i.e., the $\mathrm{O}_{2}$ partial pressure that
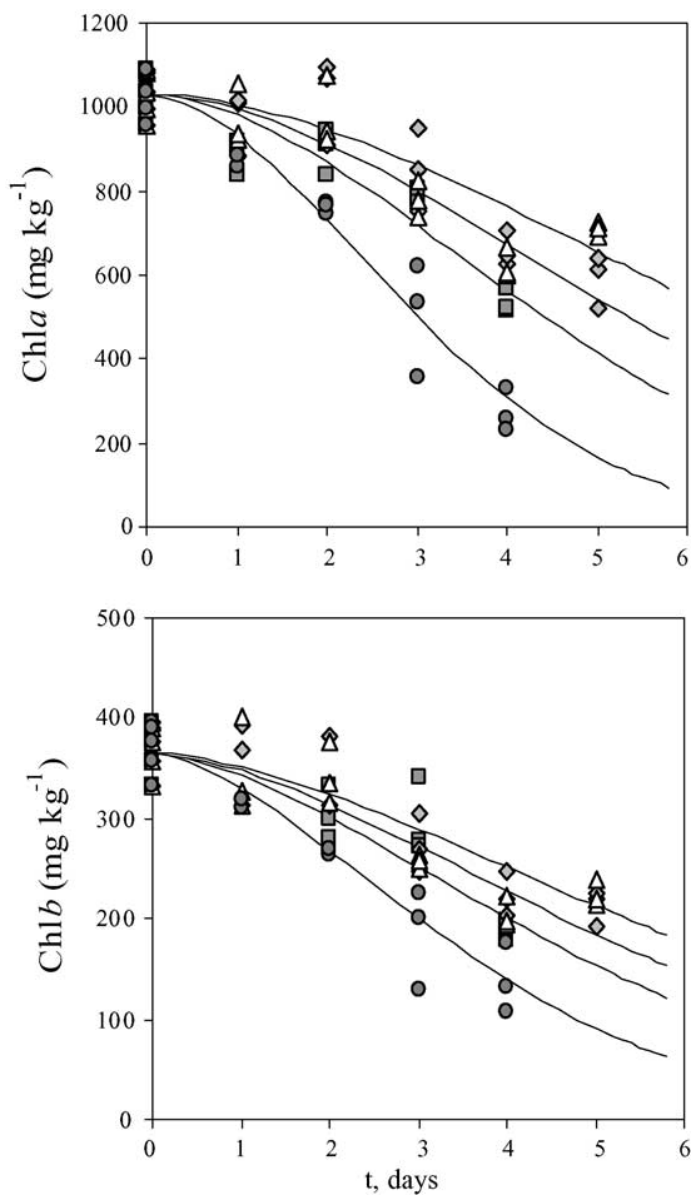

Fig. 5. Chlorophyll $a$ and $b$ degradation in shredded Galega kale stored in air $(\bullet), 10 \mathrm{kPa} \mathrm{CO}_{2}(\square), 15 \mathrm{kPa} \mathrm{CO}_{2}(\diamond)$ or $20 \mathrm{kPa} \mathrm{CO}_{2}$ $(\triangle)$ at $20^{\circ} \mathrm{C}$. The lines are the model fit (Eqs. (7) and (9)).

induces fermentative metabolism) with increased $\mathrm{CO}_{2}$ partial pressure for apple and blueberry, whereas Jurin and Karel (1963) observed no influence of high $\mathrm{CO}_{2}$ on the $\mathrm{O}_{2}$ tolerance of apple. Kader (1989) reported a decrease in the $\mathrm{O}_{2}$ tolerance limit of pears with decreasing temperature, as did Beaudry and Gran (1993) for apples and blueberries. In this case, commercial use of an $\mathrm{O}_{2}$ tolerance limit determined at the upper end of the expected range of handling temperatures would reduce the risk of fermentation if temperature fluctuations occur. On the other hand, $\mathrm{CO}_{2}$ tolerance has been shown to decrease as temperatures decrease for snap beans (Costa et al., 1994) and mangoes (Bender, 1996). 
Table 4

Colour parameters and ascorbic acid content of shredded Galega kale stored in high $\mathrm{CO}_{2}$ atmospheres and in air at $20^{\circ} \mathrm{C}$ (average \pm S.D.)

\begin{tabular}{|c|c|c|c|c|c|}
\hline \multirow[t]{2}{*}{ Physicochemical parameters } & \multirow[t]{2}{*}{$t$ (days) } & \multicolumn{4}{|c|}{ Storage atmosphere } \\
\hline & & Air & $10 \mathrm{kPaCO}_{2}$ & $15 \mathrm{kPa} \mathrm{CO} 2$ & $20 \mathrm{kPa} \mathrm{CO}_{2}$ \\
\hline$L^{*} \pm$ S.D. & $\begin{array}{l}0 \\
1 \\
2 \\
3 \\
4 \\
5\end{array}$ & $\begin{array}{c}35 \pm 3 \\
35 \pm 2 \\
37 \pm 6 \\
38.4 \pm 0.1 \\
38 \pm 4\end{array}$ & $\begin{array}{c}- \\
33 \pm 3 \\
34 \pm 2 \\
37 \pm 3 \\
34 \pm 2 \\
36 \pm 3\end{array}$ & $\begin{array}{c}- \\
35 \pm 4 \\
37 \pm 3 \\
34 \pm 3 \\
34 \pm 3 \\
35 \pm 3\end{array}$ & $\begin{array}{c}- \\
37 \pm 2 \\
33 \pm 3 \\
35 \pm 2 \\
34 \pm 2 \\
33 \pm 2\end{array}$ \\
\hline$a^{*} \pm$ S.D. & $\begin{array}{l}0 \\
1 \\
2 \\
3 \\
4 \\
5\end{array}$ & $\begin{array}{c}-14 \pm 1 \\
-14 \pm 1 \\
-13 \pm 2 \\
-11 \pm 1 \\
-8 \pm 1 \\
-\end{array}$ & $\begin{array}{c}- \\
-14 \pm 1 \\
-13 \pm 1 \\
-12 \pm 2 \\
-10 \pm 1 \\
-9.2 \pm 0.5\end{array}$ & $\begin{array}{c}- \\
-13 \pm 1 \\
-13 \pm 1 \\
-12 \pm 1 \\
-10 \pm 1 \\
-9 \pm 1\end{array}$ & $\begin{array}{c}- \\
-15 \pm 1 \\
-13 \pm 1 \\
-12 \pm 1 \\
-11 \pm 1 \\
-10 \pm 1\end{array}$ \\
\hline$b^{*} \pm$ S.D. & $\begin{array}{l}0 \\
1 \\
2 \\
3 \\
4 \\
5\end{array}$ & $\begin{array}{c}20 \pm 2 \\
20 \pm 3 \\
22 \pm 4 \\
22 \pm 3 \\
25 \pm 1 \\
-\end{array}$ & $\begin{array}{c}- \\
20 \pm 2 \\
19 \pm 2 \\
19 \pm 3 \\
19 \pm 1 \\
19 \pm 2\end{array}$ & $\begin{array}{l}- \\
18 \pm 2 \\
18 \pm 3 \\
17 \pm 2 \\
18 \pm 1 \\
17 \pm 2\end{array}$ & $\begin{array}{c}- \\
22 \pm 2 \\
19 \pm 2 \\
18 \pm 2 \\
17 \pm 2 \\
17 \pm 1\end{array}$ \\
\hline$\Delta E \pm$ S.D. & $\begin{array}{l}1 \\
2 \\
3 \\
4 \\
5\end{array}$ & $\begin{array}{l}3 \pm 1 \\
5 \pm 3 \\
5 \pm 1 \\
9 \pm 1 \\
-\end{array}$ & $\begin{array}{l}- \\
3 \pm 2 \\
4 \pm 3 \\
5 \pm 1 \\
6 \pm 1\end{array}$ & $\begin{array}{l}- \\
4 \pm 3 \\
5 \pm 2 \\
5 \pm 2 \\
6 \pm 1\end{array}$ & $\begin{array}{l}- \\
4 \pm 3 \\
4 \pm 2 \\
5 \pm 2 \\
6 \pm 2\end{array}$ \\
\hline $\mathrm{AA} \pm$ S.D. $\left(\mathrm{mg} \mathrm{kg}^{-1}\right)$ & $\begin{array}{l}0 \\
1 \\
3 \\
4 \\
5\end{array}$ & $\begin{array}{l}521 \pm 39 \\
526 \pm 8 \\
216 \pm 27 \\
102 \\
\quad-\end{array}$ & $\begin{array}{l}\quad- \\
293 \pm 12 \\
261 \pm 8 \\
245 \\
56 \pm 8\end{array}$ & $\begin{array}{c}- \\
439 \pm 4 \\
352 \pm 24 \\
180 \pm 70 \\
82 \pm 35\end{array}$ & \begin{tabular}{l}
\multicolumn{1}{c}{} \\
$483 \pm 15$ \\
$219 \pm 16$ \\
202 \\
$212 \pm 15$
\end{tabular} \\
\hline
\end{tabular}

$\mathrm{CO}_{2}$ production rates were greater in air than in the atmosphere combinations tested (Fig. 6), but no differences were found among the different combinations of low $\mathrm{O}_{2}$ plus high $\mathrm{CO}_{2}$ partial pressures tested except for the $2 \mathrm{kPa} \mathrm{O}_{2}$ plus $15 \mathrm{kPa} \mathrm{CO}_{2}$ treatment, which maintained low respiration for only $2 \mathrm{~d}$ before increasing two-fold over the next $2 \mathrm{~d}$. No changes in respiration rate were observed over storage time. The RQ values did not indicate anaerobic fermentation (data not shown).

Shredded Galega kale stored in low $\mathrm{O}_{2}$ plus high $\mathrm{CO}_{2}$ partial pressures maintained its sensory quality longer than samples stored in air (Table 5). The combined low $\mathrm{O}_{2}$ plus high $\mathrm{CO}_{2}$ atmosphere combinations increased product shelf life from $2.7 \mathrm{~d}$ in air up to $4.5 \mathrm{~d}$ : storage in an atmosphere resulting from combining the lower partial pressures of $\mathrm{O}_{2}$ and higher of $\mathrm{CO}_{2}$ in the ranges tested yielded a shelf life of $4 \mathrm{~d}$ for the $1 \mathrm{kPa} \mathrm{O}_{2}$ plus $15 \mathrm{kPa} \mathrm{CO}$ treatment and all the other combinations tested led to $4.5 \mathrm{~d}$. Thus, the combination of low $\mathrm{O}_{2}$ and high $\mathrm{CO}_{2}$ partial pressures increases shelf life similar to those found for low $\mathrm{O}_{2}$ atmospheres, with no synergistic effects of low $\mathrm{O}_{2}$ and high $\mathrm{CO}_{2}$. It is curious to note that the shelf life of samples stored in air was close to $3 \mathrm{~d}$, longer than previously observed ( 2 and $2.2 \mathrm{~d}$ ). This may be explained by differences in the quality of the raw material, owing to climactic variations. Samples analysed in this latter experiment had a lower respiration rate in air and a lower water content $\left(856 \pm 7 \mathrm{~g} \mathrm{~kg}^{-1}\right)$ than samples used in the first two experiments.

It is also curious to note that off-odour dictated shelf life for all samples stored in combinations of low $\mathrm{O}_{2}$ and high $\mathrm{CO}_{2}$, whereas previously the effect had been 
Table 5

Sensory attributes of shredded Galega kale stored in low $\mathrm{O}_{2}$ and high $\mathrm{CO}_{2}$ atmospheres and in air at $20^{\circ} \mathrm{C}$

\begin{tabular}{|c|c|c|c|c|c|c|}
\hline \multirow[t]{2}{*}{ Sensory attributes } & \multirow[t]{2}{*}{$t$ (days) } & \multicolumn{5}{|l|}{ Storage atmosphere } \\
\hline & & $1 \mathrm{kPa} \mathrm{O}_{2}+20 \mathrm{kPaCO} \mathrm{CO}_{2}$ & $1 \mathrm{kPa} \mathrm{O}_{2}+15 \mathrm{kPaCO} \mathrm{CO}_{2}$ & $2 \mathrm{kPa} \mathrm{O}_{2}+20 \mathrm{kPaCO} \mathrm{CO}_{2}$ & $2 \mathrm{kPa} \mathrm{O}_{2}+15 \mathrm{kPaCO}_{2}$ & Air \\
\hline \multirow[t]{6}{*}{ Off-odour } & 0 & 1 & 1 & 1 & 1 & 1 \\
\hline & 2 & 1 & 1 & 1 & 1 & 1 \\
\hline & 3 & 2 & 2 & 1 & 1 & 3 \\
\hline & 4 & 4 & 5 & 3 & 3 & 7 \\
\hline & 5 & 7 & 6 & 8 & 7 & - \\
\hline & 6 & 9 & 9 & 9 & 9 & - \\
\hline \multirow[t]{6}{*}{ Colour } & 0 & 9 & 9 & 9 & 9 & 9 \\
\hline & 2 & 9 & 9 & 9 & 9 & 7 \\
\hline & 3 & 8 & 8 & 8 & 8 & 4 \\
\hline & 4 & 7 & 7 & 7 & 7 & 1 \\
\hline & 5 & 5 & 6 & 4 & 5 & - \\
\hline & 6 & 4 & 4 & 3 & 3 & - \\
\hline \multirow[t]{6}{*}{ Visual quality } & 0 & 9 & 9 & 9 & 9 & 9 \\
\hline & 2 & 9 & 9 & 9 & 9 & 7 \\
\hline & 3 & 8 & 8 & 8 & 8 & 4 \\
\hline & 4 & 7 & 7 & 7 & 7 & 1 \\
\hline & 5 & 3 & 4 & 2 & 3 & - \\
\hline & 6 & 3 & 2 & 1 & 1 & - \\
\hline
\end{tabular}

The values show the rating in a 1-9 scale index.

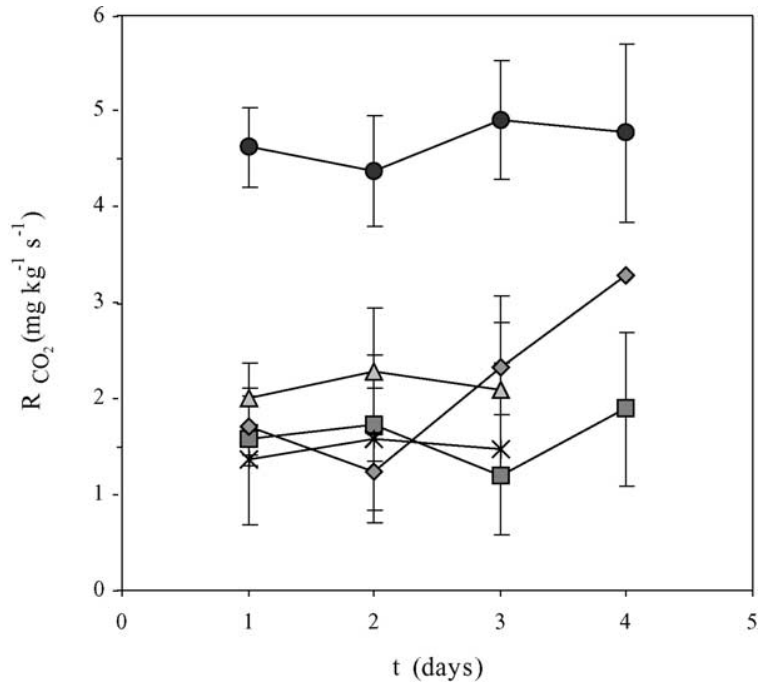

Fig. 6. $\mathrm{CO}_{2}$ production rate of shredded Galega kale stored in air $(\circlearrowleft), 2 \mathrm{kPa} \mathrm{O}_{2}$ plus $20 \mathrm{kPa} \mathrm{CO}_{2}(\square), 2 \mathrm{kPa} \mathrm{O}$ plus $15 \mathrm{kPa} \mathrm{CO}_{2}(\diamond)$, $1 \mathrm{kPa} \mathrm{O}_{2}$ plus $20 \mathrm{kPaCO}_{2}(\triangle)$ or $1 \mathrm{kPa} \mathrm{O}$ plus $15 \mathrm{kPa} \mathrm{CO}_{2}(\Psi)$ at $20^{\circ} \mathrm{C}$ (average of three replicates \pm S.D.). critical only for samples stored in $1 \mathrm{kPaO}_{2}$. This shows that, although combinations of low $\mathrm{O}_{2}$ and high $\mathrm{CO}_{2}$ partial pressures yielded shelf life results very similar to those found for low $\mathrm{O}_{2}$ atmospheres, the degradation mechanisms appeared to be different. Off-odours were first detected after $4 \mathrm{~d}$ of storage in atmospheres containing $2 \mathrm{kPa} \mathrm{O}_{2}$ and after $3 \mathrm{~d}$ in all the other conditions tested. Visual quality was also a limiting attribute for all samples except for those stored in $1 \mathrm{kPa} \mathrm{O}_{2}+15 \mathrm{kPa}$ $\mathrm{CO}_{2}$, and colour was a critical factor only for samples stored in air. These results confirm that colour is the sensory attribute that mostly benefited from the low $\mathrm{O}_{2}$ plus high $\mathrm{CO}_{2}$ atmosphere combinations tested. Sensory inspection could not differentiate between the combinations of low $\mathrm{O}_{2}$ and high $\mathrm{CO}_{2}$ tested, except for samples stored in $1 \mathrm{kPa} \mathrm{O}+15 \mathrm{kPa} \mathrm{CO}$, which showed for some storage times a better retention of colour but a faster development of off-odours (Table 5). Analysis of variance could not differentiate between the $L^{*}, a^{*}, b^{*}$, and $\Delta E$ values of different low $\mathrm{O}_{2}$ plus high $\mathrm{CO}_{2}$ atmosphere combinations tested, but clearly the air control was different from CA (Table 6). The $a^{*}$ value increased during storage in all atmospheres tested, indicating a loss of green colour, in contrast to the other values, which increased over time only in 
air. Thus, no yellowing was detected in samples stored in the atmosphere combinations tested. Degradation of $\mathrm{Chl}$ was much faster in air than in the low $\mathrm{O}_{2}$ plus high $\mathrm{CO}_{2}$ atmospheres and no differences existed among the latter (Table 6). The ratio of Chl $a$ to $b$ increased during storage time. Degradation of AA during storage was faster in samples stored in air than in low $\mathrm{O}_{2}$ plus high $\mathrm{CO}_{2}$ treatments (Table 6).

Table 6

Colour parameters, and chlorophyll and ascorbic acid contents of shredded Galega kale stored in low $\mathrm{O}_{2}$ and high $\mathrm{CO}_{2}$ atmospheres and in air at $20^{\circ} \mathrm{C}$ (average \pm S.D.)

\begin{tabular}{|c|c|c|c|c|c|c|}
\hline \multirow{2}{*}{$\begin{array}{l}\text { Physicochemical } \\
\text { parameters }\end{array}$} & \multirow[t]{2}{*}{$t$ (days) } & \multicolumn{5}{|c|}{ Storage atmosphere } \\
\hline & & $\begin{array}{l}1 \mathrm{kPaO}_{2} \\
+20 \mathrm{kPa} \mathrm{CO}\end{array}$ & $\begin{array}{l}1 \mathrm{kPa} \mathrm{O}_{2} \\
+15 \mathrm{kPa} \mathrm{CO}\end{array}$ & $\begin{array}{l}2 \mathrm{kPa} \mathrm{O}_{2} \\
+20 \mathrm{kPa} \mathrm{CO}\end{array}$ & $\begin{array}{l}2 \mathrm{kPa} \mathrm{O}_{2} \\
+15 \mathrm{kPa} \mathrm{CO}\end{array}$ & Air \\
\hline$L^{*} \pm$ S.D. & $\begin{array}{l}0 \\
2 \\
3 \\
4 \\
5 \\
6\end{array}$ & $\begin{array}{c}- \\
39 \pm 5 \\
38 \pm 4 \\
36 \pm 3 \\
38 \pm 3 \\
38 \pm 3\end{array}$ & $\begin{array}{c}- \\
32 \pm 3 \\
37 \pm 3 \\
35 \pm 3 \\
37 \pm 2 \\
39 \pm 3\end{array}$ & $\begin{array}{c}- \\
40 \pm 5 \\
35 \pm 4 \\
35 \pm 3 \\
36 \pm 2 \\
36 \pm 2\end{array}$ & $\begin{array}{c}- \\
38 \pm 2 \\
34 \pm 3 \\
35 \pm 2 \\
38 \pm 4 \\
36 \pm 4\end{array}$ & $\begin{array}{l}36 \pm 3 \\
34 \pm 4 \\
39 \pm 3 \\
45 \pm 5 \\
- \\
-\end{array}$ \\
\hline$a^{*} \pm$ S.D. & $\begin{array}{l}0 \\
2 \\
3 \\
4 \\
5 \\
6\end{array}$ & $\begin{array}{c}- \\
-13 \pm 1 \\
-13 \pm 2 \\
-12 \pm 1 \\
-12 \pm 1 \\
-10.9 \pm 0.3\end{array}$ & $\begin{array}{c}- \\
-13 \pm 1 \\
-12 \pm 2 \\
-11.9 \pm 0.5 \\
-12 \pm 1 \\
-11 \pm 1\end{array}$ & $\begin{array}{c}- \\
-13 \pm 1 \\
-12 \pm 1 \\
-11 \pm 1 \\
-11 \pm 1 \\
-10 \pm 1\end{array}$ & $\begin{array}{c}- \\
-13 \pm 1 \\
-12 \pm 1 \\
-10 \pm 1 \\
-11 \pm 1 \\
-11 \pm 1\end{array}$ & $\begin{array}{c}-13 \pm 1 \\
-11 \pm 1 \\
-12 \pm 1 \\
-9 \pm 1 \\
- \\
-\end{array}$ \\
\hline$b^{*} \pm$ S.D. & $\begin{array}{l}0 \\
2 \\
3 \\
4 \\
5 \\
6\end{array}$ & $\begin{array}{c}- \\
18 \pm 2 \\
17 \pm 3 \\
19 \pm 2 \\
18 \pm 2 \\
18 \pm 2\end{array}$ & $\begin{array}{l}- \\
19 \pm 2 \\
17 \pm 3 \\
17 \pm 1 \\
18 \pm 2 \\
16 \pm 2\end{array}$ & $\begin{array}{c}- \\
18 \pm 2 \\
17 \pm 2 \\
17 \pm 3 \\
17 \pm 1 \\
16 \pm 2\end{array}$ & $\begin{array}{l}- \\
17 \pm 3 \\
18 \pm 2 \\
15 \pm 1 \\
15 \pm 2 \\
16 \pm 2\end{array}$ & $\begin{array}{l}18 \pm 2 \\
17 \pm 2 \\
23 \pm 3 \\
24 \pm 1 \\
- \\
-\end{array}$ \\
\hline$\Delta E \pm$ S.D. & $\begin{array}{l}2 \\
3 \\
4 \\
5 \\
6\end{array}$ & $\begin{array}{l}5 \pm 2 \\
5 \pm 3 \\
4 \pm 2 \\
4 \pm 1 \\
4 \pm 1\end{array}$ & $\begin{array}{l}5 \pm 2 \\
4 \pm 2 \\
4 \pm 2 \\
3 \pm 1 \\
5 \pm 2\end{array}$ & $\begin{array}{l}5 \pm 3 \\
4 \pm 2 \\
4 \pm 2 \\
4 \pm 1 \\
4 \pm 1\end{array}$ & $\begin{array}{l}4 \pm 2 \\
4 \pm 2 \\
5 \pm 2 \\
5 \pm 2 \\
5 \pm 3\end{array}$ & $\begin{array}{l}4 \pm 3 \\
7 \pm 2 \\
12 \pm 3 \\
- \\
-\end{array}$ \\
\hline Chl $a \pm$ S.D. $\left(\mathrm{mg} \mathrm{kg}^{-1}\right)$ & $\begin{array}{l}0 \\
2 \\
3 \\
4 \\
5 \\
6\end{array}$ & $\begin{array}{l}\quad- \\
918 \pm 124 \\
969 \pm 24 \\
971 \pm 109 \\
948 \pm 93 \\
895 \pm 61\end{array}$ & $\begin{array}{l}\quad- \\
979 \pm 62 \\
872 \pm 114 \\
748 \pm 76 \\
938 \pm 125 \\
741 \pm 30\end{array}$ & $\begin{array}{l}- \\
899 \pm 100 \\
936 \pm 47 \\
725 \pm 19 \\
903 \pm 25 \\
818 \pm 61\end{array}$ & $\begin{array}{l}\quad- \\
976 \pm 56 \\
834 \pm 103 \\
916 \pm 19 \\
803 \pm 79 \\
764 \pm 62\end{array}$ & $\begin{array}{l}785 \pm 35 \\
852 \pm 43 \\
429 \pm 2 \\
280 \pm 28 \\
\quad- \\
-\end{array}$ \\
\hline Chl $b \pm$ S.D. $\left(\mathrm{mg} \mathrm{kg}^{-1}\right)$ & $\begin{array}{l}0 \\
2 \\
3 \\
4 \\
5 \\
6\end{array}$ & $\begin{array}{l}\quad- \\
292 \pm 55 \\
290 \pm 6 \\
285 \pm 47 \\
264 \pm 32 \\
259 \pm 12\end{array}$ & $\begin{array}{l}- \\
313 \pm 24 \\
256 \pm 42 \\
205 \pm 28 \\
266 \pm 42 \\
202 \pm 4\end{array}$ & $\begin{array}{l}\quad- \\
277 \pm 41 \\
278 \pm 20 \\
215 \pm 2 \\
268 \pm 17 \\
249 \pm 22\end{array}$ & $\begin{array}{c}- \\
319 \pm 28 \\
245 \pm 35 \\
288 \pm 19 \\
241 \pm 36 \\
219 \pm 34\end{array}$ & $\begin{array}{c}238 \pm 14 \\
289 \pm 26 \\
129 \pm 8 \\
88 \pm 10 \\
- \\
-\end{array}$ \\
\hline $\mathrm{AA} \pm$ S.D. $\left(\mathrm{mg} \mathrm{kg}^{-1}\right)$ & $\begin{array}{l}0 \\
3 \\
4 \\
5 \\
6\end{array}$ & $\begin{array}{c}- \\
589 \pm 4 \\
369 \pm 19 \\
411 \pm 27 \\
448 \pm 61\end{array}$ & $\begin{array}{c}- \\
580 \pm 94 \\
433 \pm 39 \\
448 \pm 38 \\
395 \pm 19\end{array}$ & $\begin{array}{c}- \\
435 \pm 49 \\
397 \pm 50 \\
341 \pm 12 \\
251 \pm 12\end{array}$ & $\begin{array}{c}- \\
613 \pm 04 \\
394 \pm 54 \\
273 \pm 15 \\
282 \pm 123\end{array}$ & $\begin{array}{c}514 \pm 21 \\
367 \pm 49 \\
251 \pm 8 \\
- \\
-\end{array}$ \\
\hline
\end{tabular}


Table 7

Parameters of the mathematical model (Eqs. (7) and (8)) predicting chlorophyll degradation as a function of time and $\mathrm{O}_{2}$ partial pressure at $20{ }^{\circ} \mathrm{C}$ (without $\mathrm{CO}_{2}$ ), and relevant statistical data

\begin{tabular}{llllll}
\hline & $\mathrm{Chl}_{\mathrm{i}} \pm \mathrm{CI}\left(\mathrm{mg} \mathrm{kg}^{-1}\right)$ & $\alpha_{1} \pm \mathrm{CI}(\mathrm{s})$ & $\alpha_{2} \pm \mathrm{CI}(\mathrm{kPa})$ & $\beta \pm \mathrm{CI}($ dimensionless $)$ & $R^{2}(\%)$ \\
\hline $\mathrm{Chl} a$ & $812 \pm 26$ & $150 \pm 12$ & $14.5 \pm 0.6$ & $2.4 \pm 0.6$ & 89.0 \\
$\mathrm{Chl} b$ & $267 \pm 12$ & $156 \pm 24$ & $14 \pm 1$ & $2.1 \pm 0.6$ & 79.8 \\
\hline
\end{tabular}

CI: confidence interval at $95 \%$ significance level, $R^{2}$ : coefficient of determination.

Table 8

Parameters of the mathematical model (Eqs. (7) and (9)) predicting chlorophyll degradation as a function of time and $\mathrm{CO}_{2}$ partial pressure at $20^{\circ} \mathrm{C}$ (with $21 \mathrm{kPa} \mathrm{O}_{2}$ ), and relevant statistical data

\begin{tabular}{llllll}
\hline & $\mathrm{Chl}_{\mathrm{i}} \pm \mathrm{CI}\left(\mathrm{mg} \mathrm{kg}^{-1}\right)$ & $\alpha_{3} \pm \mathrm{CI}(\mathrm{s})$ & $\alpha_{4} \pm \mathrm{CI}(\mathrm{kPa})^{-1}$ & $\beta \pm \mathrm{CI}($ dimensionless $)$ & $R^{2}(\%)$ \\
\hline $\mathrm{Chl} a$ & $1030 \pm 30$ & $216 \pm 24$ & $0.038 \pm 0.008$ & $1.8 \pm 0.4$ & 88.4 \\
$\mathrm{Chl} b$ & $365 \pm 12$ & $246 \pm 36$ & $0.029 \pm 0.008$ & $1.6 \pm 0.4$ & 83.7 \\
\hline
\end{tabular}

CI: confidence interval at $95 \%$ significance level, $R^{2}$ : coefficient of determination.

\section{Chlorophyll degradation modelling}

The kinetics of chlorophyll $a$ and $b$ degradation of shredded Galega kale were the only factors that could be modelled, as degradation of the other quality characteristics monitored either did not occur to a significant extent or the scatter in the data was too high. Chlorophyll degradation was modelled according to a Weibull model:

$\mathrm{Chl}=\mathrm{Chl}_{\mathrm{i}} \times \exp \left[-\left(\frac{t}{\alpha}\right)^{\beta}\right]$

where $\mathrm{Chl}_{\mathrm{i}}$ is the initial chlorophyll concentration and $\alpha$ and $\beta$ are the time and shape model parameters, respectively.

This model was not applied to the experiments with low $\mathrm{O}_{2}$ plus high $\mathrm{CO}_{2}$ combination, as in those atmospheres chlorophyll degradation was negligible. The influence of gas composition on the model parameters was analysed for each set of conditions. It was found that $\beta$ was not affected by the atmosphere composition, whereas $\alpha$ decreased exponentially with increasing $\mathrm{O}_{2}$ partial pressure (Eq. (8)) and increased exponentially with increasing $\mathrm{CO}_{2}$ partial pressure (Eq. (9)):

$\alpha=\alpha_{1}+\exp \left(\frac{\alpha_{2}}{y_{\mathrm{O}_{2}}}\right)$

$\alpha=\alpha_{3} \times \exp \left(\alpha_{4} \times y_{\mathrm{CO}_{2}}\right)$

where $\alpha_{1}, \alpha_{2}, \alpha_{3}$, and $\alpha_{4}$ are the model parameters.
This shows that the mechanism of chlorophyll degradation appears to be the same for the different atmospheres tested, but degradation rates increase with increasing $\mathrm{O}_{2}$ partial pressures and decrease with increasing $\mathrm{CO}_{2}$ partial pressures ( $\beta$ is a shape parameter, that is related to degradation mechanism, and $\alpha$ is a time constant, the reciprocal being the rate constant). Two non-linear regressions were applied to the experimental data of the low $\mathrm{O}_{2}$ and the high $\mathrm{CO}_{2}$ experiments, substituting Eqs. (8) or (9) in Eq. (7), respectively. Parameter estimates for both non-linear regressions (Tables 7 and 8) gave reasonable fits to the experimental data (Figs. 3 and 5).

\section{Conclusions}

The beneficial effects of low $\mathrm{O}_{2}$ and high $\mathrm{CO}_{2}$ on quality of shredded Galega kale was manifested by extension of the sensory characteristics, reduction in respiration rate, greater $\mathrm{Chl}$ retention, and retardation of AA degradation. Both low $\mathrm{O}_{2}$ and high $\mathrm{CO}_{2}$ atmospheres had a positive effect on shelf life extension of shredded Galega kale. In the ranges tested, the effect of low $\mathrm{O}_{2}$ was greater than that of high $\mathrm{CO}_{2}$. The lowest partial pressure of $\mathrm{O}_{2}$ and the highest partial pressure of $\mathrm{CO}_{2}$ tested were found to be, respectively, high and low enough to avoid induction of anaerobic conditions. Atmospheres combining low $\mathrm{O}_{2}(1-2 \mathrm{kPa})$ with high $\mathrm{CO}_{2}$ $(15-20 \mathrm{kPa})$ partial pressures showed that the shelf life of fresh shredded Galega kale at $20^{\circ} \mathrm{C}$ can be extended from 2 to $3 \mathrm{~d}$ (in air storage), to 4 to $5 \mathrm{~d}$. 
Colour and visual quality were the critical factors limiting shelf life of shredded kale in air and in high $\mathrm{CO}_{2}$ storage, whereas off-odour and/or visual quality limited shelf life in the other conditions tested. Samples stored in air were not acceptable after $2-3 \mathrm{~d}$ because of yellowing, while samples stored in low $\mathrm{O}_{2}$ plus high $\mathrm{CO}_{2}$ atmosphere combinations were not acceptable after $4-5 \mathrm{~d}$ because of off-odour. Further research is necessary to assess microbial aspects before the best conditions for storage of shredded Galega kale can be recommended.

\section{Acknowledgements}

This research was supported by the Florida Agricultural Experiment Station with financial support for the first author from FCT, program Praxis XXI, Portugal, and approved for publication as Journal Series No. R-09336.

\section{References}

Ahvenainen, R., 1996. New approaches in improving the shelf life of minimally processed fruit and vegetables. Trends Food Sci. Technol. 7, 179-187.

Ballantyne, A., Stark, R., Selman, J.D., 1988. Modified atmosphere packaging of shredded lettuce. Int. J. Food Sci. Technol. 23, 267-274.

Barth, M.M., Kerbel, E.L., Perry, A.K., Schmidt, S.J., 1993. Modified atmosphere packaging affects ascorbic acid, enzyme activity and market quality of broccoli. J. Food Sci. 58, 140-143.

Bender, R.J., 1996. Elevated $\mathrm{CO}_{2}$ in controlled atmosphere storage and regulation of mango ripening. Ph.D. dissertation, University of Florida, Gainesville, p. 169.

Beaudry, R.M., Gran, C.D., 1993. Using a modified atmosphere packaging approach to answer some postharvest questions: factors influencing the lower oxygen limit. Acta Hortic. 326, 203-212.

Brackett, R.E., 1994. Microbiological spoilage and pathogens in minimally processed refrigerated fruit and vegetables. In: Wiley, R.C. (Ed.), Minimally Processed Refrigerated Fruit and Vegetables. Chapman and Hall, New York, pp. 269-312.

Brecht, P.E., 1980. Use of controlled atmospheres to retard deterioration of produce. Food Technol. 34 (3), 45-50

Costa, M.A.C., Brecht, J.K., Sargent, S.A., Huber, D.J., 1994. Tolerance of snap beans to elevated $\mathrm{CO}_{2}$ concentrations. Proc. Fla State Hortic. Soc. 107, 271-273.

Ezell, B.D., Wilcox, M.S., 1959. Loss of Vitamin C in fresh vegetables as related to wilting and temperature. J. Agric. Food Chem. 7, 507-509.
Gran, C.D., Beaudry, R.M., 1993. Determination of the low oxygen limit for several commercial apple cultivars by respiratory quotient breakpoint. Postharvest Biol. Technol. 3, 259267.

Gross, J. (Ed.), 1991. Pigments in Vegetables: Chlorophylls and Carotenoids. Van Nostrand Reinhold, New York.

Isenberg, F.M.R., 1979. Controlled atmosphere storage of vegetables. Hortic. Rev. 1, 337-394.

Jurin, V., Karel, M., 1963. Studies on control of respiration of McIntosh apples by packaging methods. Food Technol. 17 (6), 104-108.

Kader, A.A., 1986. Biochemical and physiological basis for effects of controlled and modified atmospheres on fruit and vegetables. Food Technol. 40 (5), 99-104.

Kader, A.A., 1989. Mode of action of oxygen and carbon dioxide on postharvest physiology of 'Bartlett' pears. Acta Hortic. 258, 161-167.

Kader, A.A., Saltveit, M.E., 2002a. Atmosphere modification. In: Bartz, J.A., Brecht, J.K. (Eds.), Postharvest Physiology and Pathology of Vegetables. Marcel Dekker, New York, pp. 229-246.

Kader, A.A., Saltveit, M.E., 2002b. Respiration and gas exchange. In: Bartz, J.A., Brecht, J.K. (Eds.), Postharvest Physiology and Pathology of Vegetables. Marcel Dekker, New York, pp. 7-29.

Kader, A.A., Zagory, D., Kerbel, E.L., 1989. Modified atmosphere packaging of fruit and vegetables. Crit. Rev. Food Sci. 28, 1-30.

Khachik, F., Beecher, G.R., Whittaker, N.F., 1986. Separation, identification and quantification of the major carotenoid and chlorophyll constituents in extracts of several green vegetables by liquid chromatography. J. Agric. Food Chem. 34, 603-616.

Matile, P., Hörtensteiner, S., Thomas, H., Kräutler, B., 1996. Chlorophyll breakdown in senescent leaves. Plant Physiol. 112, 1403-1409.

Moran, R., 1982. Formulae for determination of chlorophyllous pigments extracted with $N, N$-dimethylformamide. Plant Physiol. 69 , 1376-1381.

Qi, L., Watada, A.E., 1997. Quality changes of fresh-cut fruit in CA storage. In: Gorny, J.R. (Ed.), Proceedings of the 7th Int. Controlled Atm. Res. Conference. University of California, Davis, vol. 5, pp. 116-122.

Seber, G.A.F., Wild, C.J., 1989. Growth models. In: Nonlinear Regression. John Wiley and Sons, New York, pp. 325-340.

Smock, R.M., 1979. Controlled atmosphere storage of fruit. Hortic. Rev. 1, 301-336.

Solomos, T., Kanellis, A., 1989. Low oxygen and fruit ripening. Acta Hortic. 258, 151-160.

Terada, M., Watanabe, Y., Kunitomo, M., Hayashi, E., 1978. Differential rapid analysis of ascorbic acid and ascorbic acid 2-sulfate by dinitrophenylhydrazine. Anal. Biochem. 84, 604-608.

Weibull, W., 1951. A statistical distribution function of wide applicability. J. Appl. Mech. 18, 293-297.

Zagory, D., Kader, A.A., 1989. Quality maintenance in fresh fruit and vegetables by controlled atmospheres. In: Jen, J.J. (Ed.), Quality Factors of Fruit and Vegetables. American Chemical Society, Washington, DC, pp. 174-188. 